Драгица Радетић

Народна библиотека Бор

dragica.radetic60@gmail.com
Стручни рад

UDK 025.22(497.11)"2008/2018"

https://doi.org/10.18485/bibliotekar.2019.61.2.2

\title{
ОТКУП КЫИГА ЗА БИБЛИОТЕКЕ: ПРЕЛАЗАК КВАЛИТЕТА У КВАНТИТЕТ
}

Сажетак: У раду се коментаришу ефекти и последице актуелног модела откупа публикација за библиотеке Министарства културе и информисања Републике Србије на квалитет фондова малих и библиотека чији оснивачи не обезбеђују средства довољна да се фондови тих библиотека принављају у складу са националним стандардима. Квалитет фондова који се одржавају и попуњавају превасходно путем откупа, а који укључује све већи број наслова који су обавезни и све драстичније ограничава избор самих библиотека, сагледава се не само из перспективе вредности самих публикација, које библиотеке треба да промовишу и дистрибуирају, већ и из перспективе обавезе јавне библиотеке да одговори на захтеве и потребе својих корисника.

Кључне речи: откуп публикација за библиотеке, јавна библиотека, набавка библиотечко-информационе грађе, Закон о библиоиечко-информационој gелатиносиии.

Набавка библиотечко-информационе грађе један је од најодговорнијих послова у јавној библиотеци. Посао библиотекара који планирају и спроводе набавку у библиотекама захтева стручно знање, правовремену и темељну информисаност о актуелној издавачкој и културној продукцији, изврсно познавање постојећег фонда библиотеке, као и интересовања и потреба корисника, пре свега читалаца. Осим тога, доследна примена Закона о јавним набавкама од 2013. године посао набавке књига у библиотекама додатно је искомпликовала, јер захтева спровођење дуготрајног поступка и припрему обимне пропратне документације.

Куповини публикација, као једном од најважнијих видова набавке, приступа се промишљено и рационално, с обзиром на ограничена, нај- 
чешће недовољна финансијска средства одобрена за ту намену. У односу на потражњу корисника са листе дезидерата важно је одредити приоритете, а то подразумева садржајно квалитетније публикације. Када се бирају наслови публикација из текуће издавачке продукције, посао је још захтевнији, тражи време, знање, интуицију, односно способност предвиђања прихваћености нове књиге од стране будућих читалаца и истанчан читалачки укус библиотекара за набавку, посебно када се има у виду данашња хиперпродукција књига у којој површност и осредњост преовлађују над квалитетом.

Када је реч о прихватању поклона библиотеци, води се рачуна о томе да се фонд библиотеке не оптерећује непотребним бројем истих наслова, примерцима који су већ оштећени, по садржају неактуелни или неприкладни за коришћење у јавним библиотекама. Критички однос према поклону је методолошки утемељен, с унапред одређеним и прецизно дефинисаним критеријумима.

Због комплексности посла одговорне јавне библиотеке углавном имају комисију за набавку, чији се рад заснива на осмишљеној набавној политици, и одговарајући акт у којем су дефинисана општа начела и критеријуми избора нових наслова. Међутим, због хроничног недостатка финансијских средстава, куповина књига је често испод нивоа који се предвиђа националним стандардима за јавне библиотеке, а дешава се и да у потпуности изостане. Недостатак финансијских средстава потребних за куповину утиче на неизвесност планиране годишње набавке. Овај проблем се у досадашњој пракси у великој мери могао решити књигама добијеним путем откупа Министарства културе и информисања Републике Србије за јавне библиотеке, као најсигурнијим и најизвеснијим начином принављања библиотечких фондова у последњих двадесет и више година.

Број откупљених књига у односу на укупну набавку и њихов утицај на обим и годишњи раст фонда може се сагледати уколико се редовно раде анализе фонда. Као руководилац Матичне службе Народне библиотеке Бор пратим стање фонда библиотека на територији Борског округа, у општинама Бор, Неготин, Кладово и Мајданпек и периодично радим анализе, најчешће за претходну деценију. Анализе се израђују на основу годишњих извештаја о раду библиотека, података из анкета о библиотечком пословању који се прикупљају за централни регистар НБС и извештаја о надзору над стручним радом ових библиотека, са циљем да се установи раст фондова у односу на националне библиотечке стандарде, али и с намером да се сагледају слабе тачке у набавној политици и начину принављања фондова. На основу информација и података прикупљених 
у периоду од десет година и крајњих резултата добијених аналитичким приступом, мој закључак је да откуп има позитивну и компензујућу улогу у недостатку или потпуном изостанку куповине књига у библиотекама у Борском округу који је последица недовољног финансирања библиотека од стране оснивача.

У периоду од 2008. до 2018. године установљено је да удео откупа у укупној набавци библиотека Борског округа износи, у просеку, за све четири општинске библиотеке, 43\% и да је у поређењу с подацима из анализе за претходну деценију порастао за 11\%, када је просек био 32\%. Овај податак није резултат повећања укупног броја откупљених књига, него смањења броја књига набављених на други начин, првенствено куповином. Сагледавајући стање фондова појединачно по библиотекама, подаци о откупу у две библиотеке потврђују да откупљене књиге доминирају у укупној набавци, у библиотеци у Мајданпеку је њихов удео 54\%, а у Неготину - 53\%. Библиотека у Кладову је са 40\% принављала свој фонд захваљујући откупу, а у Бору је тај проценат најмањи - 25\%, што је разумљиво ако се има у виду да борска библиотека има могућности за континуирану куповину књига у броју који радикално не одступа у односу на број предвиђен стандардима.

Иако добијени подаци, као квантитативни параметри успешности набавне политике ових библиотека, не говоре о квалитету набављених публикација, полазећи од претпоставке да се откупом набављају публикације чији садржај има уметничку и научну вредност, могло би се рећи да је квалитет у фондовима у библиоткама у Мајданпеку и Неготину у већој мери заступљен него у Кладову и Бору, јер је на њиховим полицама свака друга књига добијена из откупа. Иако се овакав став о квалитету аутоматски намеће, не треба га брзоплето износити, док се не сагледају шири контекст и сви елементи који утичу на коначан закључак.

Потребно је нагласити да првобитна идеја откупа публикација Министарства културе за јавне библиотеке у Србији није била да се откупљеним књигама надомести изостанак планске куповине књига и да се тиме преузме обавеза оснивача библиотека да финансирају редовну годишњу куповину књига из локалних буџета. Откуп је замишљен тако да се захваљујући њему свим јавним библиотекама у Србији обезбеде најзначајнија дела различитих књижевних жанрова и из свих научних области, која задовољавају високе стандарде у погледу квалитета садржаја и опремљености, вредне, али и скупе књиге које библиотеке иначе не би могле купити од, углавном, скромних средстава намењених куповини.

У периоду од више од двадесет година, од када се спроводи откуп публикација, било је промена у моделу и поступку откупа, критеријумима 
за одабир и у висини износа за куповину публикација. Промене у начину спровођења откупа Министарства културе произлазиле су углавном из потребе да се откуп унапреди. Сваке године, након завршеног откупа, Министарство културе и Народна библиотека Србије су објављивали резултате окончаног поступка откупљивања књига, што је изазивало различите реакције и издавача, и библиотекара, па и корисника јавних библиотека. Уз признавање непорецивог значаја откупа, често су у јавности рад Комисије за откуп и сама продедура његовог спровођења били изложени критикама.

Као одговор на различите реакције на откуп 2015, у Градској библиотеци Панчево организована је јавна расправа на тему набавне политике библиотека и спровођења откупа за библиотеке, коју су иницирали редак-

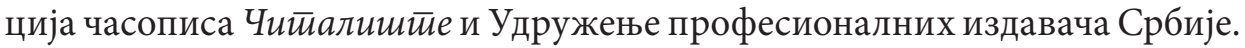
Том приликом су се чула различита мишљења, често супротстављена и искључива, од стране чланова Комисије за откуп и представника издавача и библиотекара, као равноправних учесника у откупу. ${ }^{1}$ Осим примедби изнетих на поступак одабира публикација и њихов квалитет, изнети су и веома корисни предлози и различите идеје о унапређењу откупа, углавном од стране библиотекара.

Једна од новина откупа 2015. године били су истакнути, односно наслови означени као препорука Комисије библиотекарима за дела која по својој вредности заслужују да буду одабрана у другом кругу избора, када саме библиотеке одлучују шта ће заиста узети са списка понуђених наслова. На списку публикација ови наслови су били обележени звездицом. Звездица или препорука за одређене наслове прихваћена је од стране библиотекара као помоћ у коначном избору, с тим да је у вези с њом предложено да се за овакве публикације не одваја више од 20\% од укупног износа додељеног библиотеци. На тај начин би се издавачи подстакли да објављују дела значајније уметничке и научне вредности, а истовремено би се библиотекарима оставило простора да бирају и наслове који одговарају потребама и интересовањима већине корисника. То је било корисно решење, али се у пракси примењивало само наредне две године. Одлука да се повећа проценат новца за куповину „маркираних” наслова на $30 \%$ од укупно опредељених средстава за откуп донета је већ 2017. године. У међувремену се и значење звездице уз одређене наслове преиначава од

Види „Набавна политика и спровођење откупа публикација за библиотеке Министарства културе и информисања Републике Србије”, Чийалишӣе год. 14, бр. 27 (2015): 41-59. Доступно и на: https://citaliste.rs/casopis/br27/nabavna_politika.pdf . 
препоруке у обавезу, а за куповину тих, сада обавезних, примерака износ се поново повећава у наредне две године (2018. и 2019).

Комисија за откуп 2019. године је, према пропозицијама конкурса, у оквиру свога избора обележила звездицом наслове вредне посебне пажње и то као обавезне за све библиотеке, а њихова вредност чини 40\% укупног износа одобреног за откуп. Број обавезних наслова је исти за све библиотеке без обзира на категорију којој поједине библиотеке припадају и без обзира на то колико вредност обавезних примерака захвата од укупне вредности средстава одобрених за одређени тип библиотеке. Управо је то уочено као проблем и изазвало је негативне реакције у библиотечкој заједници.

Због увођења „институције звездице” као обавезе сужава се могућност избора самих библиотекара, ограничава се њихова аутономија у остваривању плана набаке, чиме се индиректно доводе у питање знање и професионалност у обављању библиотечког посла набавке. Осим тога, одлука Комисије за откуп да број обавезних примерака буде исти за све библиотеке, независно од тога којој категорији нека библиотека припада, односно коликим буџетом располаже, доводи до парадокса да је за мале библиотеке, из прве и друге категорије, могућност даљег избора практично сведена на минимум јер обавезни примерци по вредности захватају и до 99\% укупног буџета којим оне располажу за откуп.

Не оспорава се значај откупљених „књига са звездицом”, које свакако завређују да буду на библиотечким полицама, али уколико је откуп најзаступљенији или чак једини начин принављања фонда неке библиотеке, већина корисника библиотеке остаје ускраћена за тражене наслове, јер књиге добијене из откупа, без обзира на њихову вредност, у највећој мери одговарају мањем броју, рекли бисмо само повлашћених или посвећених читалаца. А рад јавних библиотека није усмерен само на читаоце који су интелектуално „дорасли” врхунској литератури, него на кориснике свих социјалних, старосних и образовних категорија и на њихове хетерогене и с временом промењиве потребе. Библиотекари знају да њихове читаоце не занимају стандарди издаваштва, библиотечки стандарди или вредносни стандарди којим се руководе ауторитативни чланови Комисије за откуп при избору књига. Они имају своје стандарде, личне вредносне системе, своје мотиве и укус, који је са читалачким стажом подложан променама. На њихов избор могу да утичу медији, околина и библиотекари, али и не морају. Иако библиотекари својим препорукама, сугестијама и организованим програмима промовишу врхунске садржаје из уметности и науке, они нажалост често остају на маргини интересовања читалаца. Феномен 
читања почива на слободи, не трпи цензуру, забрану или диктат. На ову особеност читања као слободног, истовремено интимног чина, указао је својевремено француски писац Данијел Пенак речима: „Глагол читиайи не подноси императив. Исти отпор према њему имају и неки други глаголи,

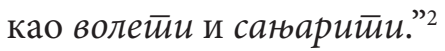

Према законски дефинисаној библиотечко-информационој делатности као делатности од општег интереса, библиотеке су у обавези да уважавају различитост интересовања и жеља свих својих чланова и да им својим услугама омогуће и обезбеде услове за слободан приступ информацијама, знањима и идејама садржаним у библиотечко-информационој грађи и изворима, као и право на остваривање њихових индивидуалних и интелектуалних слобода. ${ }^{3}$

Успех набавке библиотечке грађе процењује се степеном задовољавања потреба и интересовања корисника и мери се бројем позајмица те грађе. Када је реч о откупљеним публикацијама, библиотекари најбоље могу сагледати смисао и ефикасност откупа имајући у виду позајмице тих публикација, као примарне библиотечке услуге корисницима. Садржајно вредне књиге, уколико се не читају, представљају само квантитативну вредност. На тај начин се квалитет своди на квантитет. Незадовољство корисника понуђеним или од стране библиотекара препорученим насловима резултира њиховом незаинтересованошћу не само за те наслове, него и за библиотечке услуге уопште. А шта је књига ако се не чита? Део ентеријера, декор, симболички предмет? Књига не постоји ради себе него ради читалаца.

С обзиром на библиотечку статистику о позајмици, раније изнет став, који је требало преиспитати, да уколико набавка књига појединих библиотека значајније зависи од откупа - као што је случај са библиотекама у Мајданпеку и Неготину - утолико оне имају квалитетније књиге у својим фондовима, не потврђује се, остаје дискутабилан.

Годишњи обрт фонда (број коришћених књига подељен с укупним бројем књига у фонду) један је од најмеродавнијих параметара успешности рада сваке јавне библиотеке. Он је одређен националним стандардима према којима је потребно да јавна библиотека „обрне” свој фонд најмање два пута у току године. С увођењем електронске позајмице дата је могућност библиотекама да се реалније сагледа коришћење по различитим параме-

2 Danijel Penak, Kao u romanu (Čačak: Umetničko društvo Gradac, 1998), 25.

„Закон о библиотечко-информационој делатности”, Службени іласник РС бр. 52 (2011): чл. 2. Доступно и на: https://www.nb.rs/view_file.php?file_id=3047 (преузето 18. 9. 2019). 
трима, између осталих и по начину набавке. Уколико желимо да знамо у којој мери се позајмљују или користе у читаоници све књиге набављене путем откупа, или само књиге откупљене као обавезни примерци (наслови са звездицом), податак се може добити брзо и једноставно. Ови подаци се могу прикупљати и пратити за било који временски период и за различите намене, на пример за полугодишњи или годишњи извештај. Међутим, уколико се желе извести ваљани закључци о ефикасности откупљених публикација у односу на њихово коришћење, потребан је дужи временски период. Дакле, кроз вишегодишње праћење података о коришћењу „обавезних примерака" моћи ће се боље сагледати колико су те књиге биле у домену интересовања корисника библиотеке, да ли су и у којој мери биле део стварних корисничких потреба и потражње или су, стојећи на полицама посебних фондова, углавном биле неактуелне. Време ће показати.

Осим откупљених књига којима је комисија „звездицом” дала статус обавезних примерака за библиотеке, на основу вредносног критеријумима, треба поменути, као новину у последње три године, и напомену о важности публикација штампаних ћириличним писмом приликом одабира за откуп. Први пут се у тексту Конкурса за откуп 2017, осим критеријума који се тичу вредности публикација, квалитета штампе, повеза и опреме издања, скреће пажња и на ћирилицу као писмо којем се даје предност, да би иста напомена била поновљена и наредне две године, 2018. и 2019: „Посебна пажња ће се обратити на вредне публикације издате на ћириличком писму". ${ }^{4}$

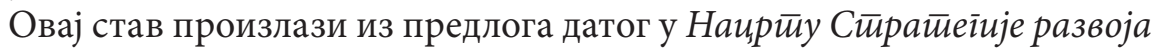
кулйире Рейублике Србије 2019-20295, али нема упориште ни у једном важећем законском пропису Србије, те не би смео бити један од усвојених критеријума за откупљивање књига за јавне библиотеке од стране Министарства културе. Срећом, увидом у списак књига које су откупљене 2019. године може се видети да Комисија за откуп није овој сугестији дала пресудну важност. Према Закону о библиоиечкко-информационој gелайнос-

4 Министарство културе и информисања Републике Србије, „Конкурс за откуп публикација за библиотеке за 2019. годину", http://www.kultura.gov.rs/lat/konkursi/konkurs-za-otkuppublikacija-za-biblioteke-za-2019--godinu (preuzeto 20. 9. 2019).

5 Општи циљ 7: Неговање српског језика и ћирилице и повезивање српског културног простора. (Народна скупштина Србије, „Стратегија развоја културе Републике Србије од 2019. до 2029: нацрт”; документ је доступан на сајту МКРС: Ministarstvo kulture i informisanja Republike Srbije, Dokumenta i propisi, http://www.kultura.gov.rs/lat/dokumenti/propisi-izoblasti-kulture/-strategija-razvoja-kulture-republike-srbije-od-2019--do-2029- (preuzeto 21. 9. 2019). 
$\bar{u} u$ обавеза библиотека је да набавља грађу за најшири круг корисника, не правећи никакве разлике међу њима, па ни оне које се тичу језика, односно писма: „Библиотеке набављају библиотечко-информациону грађу и изворе и стварају нову библиотечко-информациону грађу и изворе на основу самосталне процене стручњака, према утврђеној набавној политици, а у складу са потребама најширег круга корисника, укључујући и потребе националних, верских и језичких мањина и корисника са инвалидитетом."

У вези с тим потребно је нагласити да су јавне библиотеке установе културе отворене за све грађане, да осим сазнајне и образовне, имају естетичку и етичку фукцију, да су у улози подизања нивоа писмености, опште културе и подстицања разноликости културних израза. А неретко упућене замерке библиотекарима да су одговорни за лош укус својих читалаца тиме што набавком обухватају и књиге баналне, забавне и плитке, али за већину пријемчиве садржине, немају оправдања. Библиотеке су само слика која одражава свеукупно стање у друштву и култури, његова последица, а не узрок.

\section{Literatura:}

1. „Zakon o bibliotečko-informacionoj delatnos”. Službeni glasnik RS br. 52 (2011). Dostupno i na: https://www.nb.rs/view_file.php?file_id=3047 (preuzeto 19. 9. 2019). (na ćirilici)

2. „Nabavna politika i sprovođenje otkupa publikacija za biblioteke Ministarstva kulture i informisanja Republike Srbije". Čitalište god 14, br. 27 (2015): 41-59. (na ćirilici)

3. Narodna skupština Srbije. „Strategija razvoja kulture Republike Srbije od 2019. do 2029: nacrt". Ministarstvo kulture i informisanja Republike Srbije. Dokumenta i propisi. http://www.kultura.gov.rs/lat/dokumenti/propisi-iz-oblasti-kulture/-strategija-razvoja-kulture-republike-srbije-od-2019--do-2029- (preuzeto 21. 9. 2019). (na ćirilici)

4. Penak, Danijel. Kao u romanu. Čačak: Umetničko društvo Gradac, 1998.

6 „Закон о библиотечко-информационој делатности”, чл. 6, став 3. 


\author{
Dragica Radetić \\ Public Library Bor \\ dragica.radetic60@gmail.com
}

\title{
THE PURCHASE OF BOOKS FOR LIBRARIES BY THE MINISTRY OF CULTURE AND INFORMATION: TRANSFORMATION OF QUALITY INTO QUANTITY
}

\begin{abstract}
The paper examines and comments on some of the effects of the current model of purchase of publications for libraries by the Ministry of Culture and Information on public libraries collections, especially when we consider small and the underfinanced public libraries, whose acquisitions are highly dependent on the Ministry's purchase of books, including the obligation of purchasing marked titles that drastically limits librarians' choice and otherwise very significant opportunity for acquiring new books. The quality of libraries' collections is considered not just in relation to the usually indisputable values of the imposed titles, which a public library should certainly promote, but in relation to the public libraries legal, social and ethical obligation to respect and answer all of its users' reading habits, interests, tastes, motivations and needs as far as it is possible.
\end{abstract}

Keywords: the purchase of books for libraries, public library, acquisition of library materials, sources of information, The Low on the Library and Information Service.

Примљено: 23. октобра 2019.

Прихваћено: 12. новембра 2019. 